\title{
An Introductory Essay
}

\section{Mediterranean Perspectives on Royal Images}

\author{
Michele Bacci
}

The Book of Wisdom (also known in English as the Wisdom of Solomon) is one of the deuterocanonical texts included in the earliest Greek and Latin versions of the Bible. In scholarship, it is mostly considered to be the work of a 1st-century Alexandrian Jewish author with knowledge of Greek philosophy. ${ }^{1}$ It stands out especially for its euhemeristic explanation of the origins of idolatry, which, in the anonymous author's view, can be traced back to a distinctly human weakness, namely the irrational belief that images can act as surrogates for absent beings by simulating their physical appearance. In particular, this belief is seen when relatives are psychologically unable to overcome the crisis of sorrow caused by the death of a person dear to them: thus, the father of a young boy who had died erected a statue and loved it as if it were a living body, ultimately obliging his servants to do the same (Ws. 12-15). The text goes on to mention another reason for the emergence of idols:

Then the ungodly custom, grown strong with time, was kept as a law, and at the command of monarchs graven images were worshipped. When the people could not honour rulers in their presence, since they lived at a distance, they imagined their appearance far away, and made a visible image of the king whom they honoured, so that by their zeal they might flatter the absent one as if he were present.

Ws. 14:16-17

The text's claim is correct on historical grounds: royal images, and in particular three-dimensional ones, were frequently used in the earliest empires and, already in such contexts as Mesopotamia, were conceived of as substitutes and extensions of the king's body. ${ }^{2}$ In the Roman Empire, such ancient principles came to be reinterpreted in juridical terms, inasmuch as the ruler's simulated

1 Maurice Gilbert, La critique des dieux dans le Livre de la Sagesse (Sg 13-15) (Rome, 1984), pp. 301-13.

2 Zainab Bahrani, The Graven Image: Representation in Babylonia and Assyria (Philadelphia, 2003); Stephen L. Herring, Divine Substitution. Humanity as the Manifestation of Deity in the Hebrew Bible and the Ancient Near East (Göttingen, 2013), pp. 31-38. 
presence in imagine was deemed the institutional safeguard of the social order for all lawful citizens. In this sense, whoever approached a statue of the ruler was considered to be under the ruler's protection, and likewise any injury done to his images was an act of lese-majesty. The emperor's effigy on steelyard weights ensured the latter's lawfulness, and when exhibited in courtrooms his portrait vouched for the impartiality of judgement. On coins, it worked as sign guaranteeing the currency value. ${ }^{3}$ The function of the image as a visual marker of legitimate statehood was acknowledged even by those Jews who accepted imperial supremacy, as evident in Christ's answer to the Pharisees (Matt. 17-21) concerning whether he deemed it right to pay taxes to the Romans:

But Jesus, knowing their evil intent, said, "You hypocrites, why are you trying to trap me? Show me the coin used for paying the tax." They brought him a denarius, and he asked them, "Whose image is this? And whose inscription?" "Caesar's," they replied. Then he said to them, "So give back to Caesar what is Caesar's, and to God what is God's."

Taxes were therefore due to the authority - announced on the material surface of the coins in the form of the incumbent ruler's portrait and an inscription - who issued the currency and guaranteed its legitimacy. ${ }^{4}$ Roman subjects, including those suspicious of images, were generally inclined to accept this as a matter of fact, and it is symptomatic that even the anonymous author of the Book of Wisdom did not blame rulers for the introduction of their effigies: rather, he seemed to suggest that provincial peoples were themselves responsible for the erection of such statues in public spaces as a means of establishing and exhibiting a sort of physical relationship to their distant ruler. In this respect, the text was certainly aware of the performative contexts in which imperial images were involved as recipients of sacrifices and offerings, but at the same time it warned its readers about the subtle border separating from idolatry the use of images as embodiments of the legal order ensured by the state. The shift from image to idol was, the text recounts, by and large fostered by the material properties of the object itself, by its being fashioned

3 On the different functions and forms of Roman imperial images, see esp.: Helmut Kruse, Studien zur offiziellen Geltung des Kaiserbildes im römischen Reiche (Paderborn, 1934); Thomas Pekáry, Das römische Kaiserbildnis in Staat, Kult und Gesellschaft, dargestellt anhand der Quellen (Berlin, 1985).

4 Gerhard Wolf, Schleier und Spiegel. Traditionen des Christusbildes und die Bildkonzepte der Renaissance (Munich, 2002), pp. 3-12. 
in such a way as to invest it - and by consequence also the person there represented - with a god-like charisma (Ws. 18-20):

Then the ambition of the craftsman impelled even those who did not know the king to intensify their worship. For he, perhaps wishing to please his ruler, skilfully forced the likeness to take more beautiful form, and the multitude, attracted by the charm of his work, now regarded as an object of worship the one whom shortly before they had honored as a man.

In this way, the emperor's statue ceased to be a simple visual indicator of the effectiveness of the state-guaranteed legal order, becoming an idol, a counterfeit image that led beholders to mistake the ruler for a divinity. The shift in status was made possible by the artist's technical virtuosity, which in altering the king's appearance made it distinctly attractive to its recipients. It can be assumed that the anonymous author of Wisdom would have shared the British anthropologist Alfred Gell's description of 'art' as a 'technology of enchantment': the display of artistic agency in the reshaping of a conventional image would arouse in viewers not only bewilderment and fascination but also inadequacy and inequality, making them eager to attribute superior, supernatural qualities to the represented person. ${ }^{5}$ In the Greco-Roman world, such an effect was efficaciously engendered by the evocation of lifelikeness. This mimetic effect did not consist exclusively in the realistic rendering of bodily features but also in the adoption of strongly idealized forms that proved instrumental in emphasizing the emperor's god-like status.

The divine qualities that the Roman imperial power came increasingly to boast of inescapably blurred the functional distinction between the emperor's image as a marker of institutional authority and its use as a visual strategy to invest individual rulers with charismatic efficacy and divine attributes. ${ }^{6}$ Newly converted Christians were particularly touched by this dilemma, but, in general, they rejected those forms of homage toward images that they understood to be idolatrous, while accepting their juridical, bureaucratic, and even honorific functions. It is telling that imperial statues were often quoted in patristic literature to exemplify the semiotic tension between 'image' and 'prototype' underlying the relationship between the Son and the Father: thus, for Athanasius of Alexandria, Basil of Caesarea, and Ambrose of Milan, the adoration of the former was communicated also to the latter, in much the same way

5 Alfred Gell, Art and Agency. An Anthropological Theory of Art (Oxford, 1998), pp. 71-72.

6 Manfred Clauss, Kaiser und Gott. Herrscherkult im römischen Reich (Stuttgart, 1999). 
as it was communicated from the emperor's image to the emperor himself. ${ }^{7}$ Indeed, the gradual Christianization of the empire, which deprived emperors of their god-like status, did not prevent them from using statues as material surrogates that were meant to embody authority in public spaces, epitomize the ruler's appearance on coins, weights, and official documents, and act as conveyors of his subjects' reverence and honour. ${ }^{8}$

Much of the functional and semantic ambiguity of imperial images, stemming from their involvement in ritualized, performative acts in late antique society, was inherited by the Middle Ages. This is particularly evident in Byzantium, where cult practices involving the emperor's effigy are well documented, ${ }^{9}$ and many scholars have therefore deduced that the iconoclastic controversies may have also partly originated from rulers' fears that religious icons may rival or even replace their images in conveying and embodying authority. ${ }^{10}$ If this idea has been strongly criticized (and the historical importance of Iconoclasm itself has been generally reassessed), ${ }^{11}$ it remains a matter of fact that, in their new Christian framework, the specific agency attributed to imperial images had to be renegotiated. At the beginning of the 4th century, Eusebius of Caesarea, who disapproved of the making of religious icons, was content with acknowledging that Constantine's allegiance to the new religion took certain visual forms - statues of him holding a cross or coins depicting him in a gesture of prayer, though the latter probably corresponded to the

$7 \quad$ Morten Lund Warmind, "The Cult of the Roman Emperor before and after Christianity," in The Problem of Ritual, ed. Tore Ahlbäck (Abo, 1993), pp. 211-20, esp. 216-17; Clifford Ando, Imperial Ideology and Provincial Loyalty in the Roman Empire (Berkeley, 200o), p. 239; James A. Francis, "Visual and Verbal Representation: Image, Text, Person, and Power," in $A$ Companion to Late Antiquity, ed. Philip Rousseau (Oxford, 2009), pp. 185-305, esp. 296.

8 Maijastina Kahlos, "The Emperor's New Images - How to Honour the Emperor in the Christian Roman Empire?," in Emperors and the Divine: Rome and Its Influence, ed. Maijastina Kahlos (Helsinki, 2016), pp. 119-38.

9 Hans Belting, Bild und Kult. Eine Geschichte des Bildes vor dem Zeitalter der Kunst (Munich, 199o), pp. 119-22, 153-59; Antony Eastmond, "Between Icon and Idol: The Uncertainty of Imperial Images," in Icon and Word: The Power of Images in Byzantium. Studies presented to Robin Cormack, eds. Antony Eastmond, and Liz James (Aldershot, 2003), pp. 73-85; Maria Cristina Carile, "Imperial Icons in Late Antiquity and Byzantium. The iconic image of the Emperor between Representation and Presence," Ikon 9 (2016), 75-98. See Manuela Studer-Karlen's essay in this volume for a wider overview of the scholarly debate on Byzantine imperial images.

10 André Grabar, Liconoclasme byzantin (Paris, 1998), pp. 164-263; Belting, Bild und Kult, p. 181.

11 For revisionist approaches to the history of Iconoclasm, see: Leslie Brubaker, Inventing Byzantine Iconoclasm (London, 2012); Leslie Brubaker, and John F. Haldon, Byzantium in the Iconoclast Era, c. 680-850 (Cambridge, 2011). 
orant pose traditionally and cross-confessionally used to manifest religious pietas..$^{12}$ But, as the empire became an officially Christian state, the emperor's specific role in it came to be better defined on juridical and political-theoretical grounds. It can be wondered to what extent images were expected to convey new notions of rulership, including its reformulation in religious terms, e.g. by emphasizing the rhetorical assimilation of Byzantine basileis into the biblical figures of Melchizedek, David, and Solomon and especially into the former's priest-like function. ${ }^{13}$

In scholarship, images have often been taken as visual evidence of shifting approaches to the dialectic between the monarchic institution (regnum) and the religious sphere (sacerdotium) in the Middle Ages, being usually characterized as reflections of either the principle of 'divine investiture' or the notion of the king as God's representative on earth. ${ }^{14}$ Undoubtedly, visual materials have often been brought to bear on the debate surrounding sacred kingship developed in the field of medieval history and, more specifically, in studies concerning Western European theories of power by such authors as Marc Bloch, Ernst Kantorowicz, and Percy Ernst Schramm. ${ }^{15}$ In that area of scholarship, images were largely regarded as plain, iconographic evidence that could be used to further corroborate assumptions about the ideological construction of the king's function and prerogatives, without any attempt at considering the specific circumstances under which the images had been made nor the spatial, social, cultural, and performative contexts in which they had been used. Basically, it was taken for granted that royal arts - that is, all forms of artistic production

12 Steven Bigham, Early Christian Attitudes toward Images (Rollinsford, 2004), pp. 192-93, 200, 202.

13 Gilbert Dagron, Empereur et prêtre. Étude sur le "césaropapisme" byzantin (Paris, 1996), 184-9o.

14 For modern approaches to the shifting medieval theories of rulership and the latter's 'secular' and 'sacred' aspects, see esp.: Stefan Weinfurter, "Idee und Funktion des 'Sakralkönigtums' bei den ottonischen und salischen Herrschern (10. und 11.Jahrhundert)," in Legitimation und Funktion des Herrschers. Vom ägyptischen Pharao zum neuzeitlichen Diktator, eds. Rolf Gundlach, and Hermann Weber (Stuttgart, 1992), pp. 99-127; Die Sakralität von Herrschaft. Herrschaftslegitimierung im Wechsel der Zeiten und Räume, ed. Franz-Reiner Erkens (Berlin, 2002); Andreas Kosuch, Abbild und Stellvertreter Gottes. Der König in herrschaftstheoretischen Schriften des späten Mittelalters (Cologne, 2011).

15 Marc Bloch, Les rois thaumaturges. Étude sur le caractère surnaturel attribué à la puissance royale particulièrement en France et en Angleterre (Strasbourg, 1924); Percy Ernst Schramm, Die deutschen Kaiser und Könige in Bildern ihrer Zeit bis zur Mitte 12. Jahrhunderts (751-1152) (Leipzig, 1928); Percy Ernst Schramm, and Florentine Mütherich, Denkmale der deutschen Könige und Kaiser. I. Ein Beitrag zur Herrschergeschichte von Karl dem Großen bis Friedrich II. (Munich, 1962); Ernst Kantorowicz, The King's Two Bodies. A Study in Mediaeval Political Theology (Princeton, 1947). 
promoted by courts - were to be understood as propagandistic tools illustrating and celebrating the monarch's distinctive and privileged role, described as a kind of 'sacredness' that, though appropriating features stemming from Church tradition, was by its nature autonomous and secular.

Recent research has contributed to nuancing such views by placing emphasis on the religious dimension of many of the royal images that older scholars had interpreted as merely visualizing political-theoretical ideas. It has been stressed that, frequently, royal images were not meant for public display, were not invested with self-celebratory meanings, and were not even promoted by kings or queens: it has become evident, for example, that the representation of Carolingian rulers in liturgical books or of Norman rulersin mosaics(Figure.o.1)both types of objects decorating the areas of churches reserved for the performance of the Mass - has much less to do with propaganda than it does with such issues as the depicted persons' quest for divine protection during their lifetime and for salvation in the afterlife, their desire to permanently record their spiritual association with a given religious community, or the clergy's interest in visualizing their own involvement in offering prayers for the rightfulness, success, and prosperity of their rulers. ${ }^{16}$

In this effort to deconstruct previous assumptions about the strategic use of figurative arts by rulers to claim a supernatural basis for their power, recent research has underscored rulers' religious-devotional habits, which they largely shared with their subjects. If they commissioned their images with the aim of obtaining salvation or divine assistance, the obvious conclusion would be that these images manifest broader human anxieties and expectations. It might therefore be asked whether this implied the adoption of forms that more distinctly evoked a ruler's personal appearance, rather than his 'body politic' or his capacity to embody a kind of authority that transcends time. Indeed, the lingering question concerns the long-debated dilemma of whether and to what extent the tension between the realistic and the idealized in the

16 See especially: Ludger Körntgen, Königsherrschaft und Gottes Gnade: Zu Kontext und Funktion sakraler Vorstellungen in Historiographie und Bildzeugnissen der ottonischfrühsalischen Zeit (Berlin, 2001); Ildar Garipzanov, The Symbolic Language of Authority in the Carolingian World (c. 751-877) (Leiden, 2008); Eliza Garrison, Ottonian Imperial Art and Portraiture. The Artistic Patronage of Otto III and Henry II (Farnham, 2012); Mirko Vagnoni, Dei gratia rex Siciliae. Scene d'incoronazione regia nell'iconografia regia normanna (Palermo, 2017). See also: Idem, "Meanings and Functions of Norman Royal Portraits in the Religious and Liturgical Context: The Mosaic of the Cathedral of Monreale," Iconographica 18 (2019), 26-37, and the overview of recent research in: Idem, "Royal Divine Coronation Iconography. Preliminary Considerations," Arts 8/4 (2019), 139 [https://doi.org/10.339o/arts8040139, accessed 2020 July 15]. 
rendering of the king corresponds to Kantorowicz's notional divide between his two - physical and metaphorical - bodies. In other terms, were individualized images less fit than abstract ones to evoke the supra-personal nature of the royal office?

A basic difficulty is represented, in scholarship, by the persisting use of the word 'portrait.' Even though this term was created in the Middle Ages, its modern meaning - a self-contained, individualized, and true-to-life representation of a single person - was alien to medieval cultures and, even in Western Europe, did not become commonplace earlier than the late 14th century. If monarchs from this period were among the first to promote the making of images deemed faithful in appearance to their own facial features, ${ }^{17}$ it is often difficult to ascertain to what extent, and in which ways, these individual features were typified and idealized and which specific meanings they were meant to convey. ${ }^{18}$ It can

17 For a thorough introduction to this topic, see: Stephen Perkinson, The Likeness of the King: A Prehistory of Portraiture in Late Medieval France (Chicago, 2009).

18 Among the many investigations of the complex relationship between 'portrait' and 'individual' in the Middle Ages, see esp.: Enrico Castelnuovo, "Il significato del ritratto pittorico nella società," in Storia d'Italia. V.2. I documenti (Turin, 1973), pp. 1031-94, newly republished as: Ritratto e società. Dal Medioevo all'avanguardia, eds. Fabrizio Crivello, and Michele Tomasi (Turin, 2015); Kurt Bauch, Das mittelalterliche Grabbild. Figürliche Grabmäler des 11. bis 15. Jahrhunderts in Europa (Berlin, 1976); Otto Gerhard Oexle, "Memoria und Memorialbild," in Memoria. Die geschichtliche Zeugniswert des liturgischen Gedenkens im Mittelalter, eds. Karl Schmid, and Joachim Wollasch (Munich, 1984), pp. 384-440; Michel Pastoureau, "L'effervescence emblématique et les origines héraldiques du portrait au XIV e siècle," Bulletin de la Société nationale des antiquaires de France (1985), 108-15; Andrew Martindale, Heroes, Ancestors, Relatives and the Birth of the Portrait (Maarssen, 1990); Peter Cornelius Claussen, "Ritratto," in Enciclopedia dell'arte medievale 10, ed. Angela Maria Romanini (Rome, 1991-2002), pp. 33-46; Bruno Reudenbach, "Individuum ohne Bildnis? Zum Problem künstlerischer Ausdrucksformen von Individualität im Mittelalter," in Individuum und Individualität im Mittelalter, eds. Jan A. Aerstsen, and Andreas Speyer (Berlin, 1996), pp. 807-18; Klaus Niehr, "Mimesis, Stilisierung, Fiktion in spätmittelalterlicher Porträtmalerei. Das sog. Gothaer Liebespaar," Marburger Jahrbuch für Kunstwissenschaft 25 (1998), 79-104; Die Renaissance und die Entdeckung des Individuums in der Kunst, ed. Enno Rudolph (Tübingen, 1998); The Image of the Individual. Portraits in the Renaissance, eds. Nicholas Mann, and Luke Syson (London, 1998); Hans Körner, "Individuum und Gruppe. Fragen nach der Signifikanz von Verismus und Stilisierung im Grabbild des 13. Jahrhunderts," in Die Repräsentation der Gruppen. Texte-Bilder-Objekte, eds. Otto Gerhard Oexle, and Andrea von Hülsen-Esch (Göttingen, 1998), pp. 89-126; Porträt, eds. Hannah Baader, Rudolf Preimesberger, and Nicola Suthor (Berlin, 1999); Georgia Sommers Wright, "The Reinvention of the Portrait Likeness in the Fourteenth Century," Gesta 39 (2000), 117-34; Hans Belting, Bild-Anthropologie. Entwürfe für eine Bildwissenschaft (Munich, 2001), pp. 115-42; Jean-Claude Schmitt, Le corps, le mythe, les rêves, les temps. Essais d'anthropologie médiévale (Paris, 2001), pp. 241-62; Das Porträt vor der Erfindung des Porträts, eds. Martin Büchsel, and Peter Schmidt (Mainz, 
be assumed that a strongly individualized, optically reliable, and true-to-life representation of a ruler's physiognomic features would have been considered insufficient to evoke the charismatic power of the institution he or she embodied. A realistic code could be adopted only where rulers had a specific political or diplomatic interest in making use of it. There is some evidence, for example, that portraits were used in marriage negotiations not only in the late medieval and early modern periods, ${ }^{19}$ but also earlier: according to the mid-11th-century Casus Sancti Galli, one century earlier a skilful eunuch-artist was given the task of painting a reliable likeness of the duke of Bavaria's daughter, Hadwig, so that the Byzantine emperor could ascertain whether she was beautiful enough to be chosen as his bride. The young woman, who stubbornly opposed this marriage prospect, started twisting her mouth and rolling her eyes, to make herself look unpleasant. ${ }^{20}$

Despite its legendary tone, this text indicates that, already in the High Middle Ages, it could in some circumstances prove useful to have realistic renderings of people's physiognomy, if these were instrumental to political causes. It is clear, however, that such images as Hadwig's portrait were certainly intended for a very restricted audience - the basileus himself and his counsellors, all of whom had a vested interest in knowing more about the princess's physical appearance. In the case of figural objects meant for public display, an excessively mimetic rendering of the ruler's body would have probably puzzled viewers, who were accustomed to more abstract conventions, unless other

2003); Stephen Perkinson, "Rethinking the Origins of Portraiture," Gesta 46 (2007), 135-57; Le portrait: la représentation de l'individu, eds. Agostino Paravicini Bagliani, Jean-Michel Spieser, and Jean Wirth (Florence, 2007); Le portrait individuel: réflexions autour d'une forme de représentation XIII ${ }^{e}-X V^{e}$ siècles, ed. Dominic Olariu (Bern, 20o9); Martin Büchsel, "Le portrait au Moyen Âge," Perspective 2 (2012), 401-o6; Kees Veelenturf, "In the Guise of a Christian: The Early Medieval Preliminary Stage of the Portrait Historié," in Example or Alter Ego? Aspects of the Portrait Historie in Western Art from Antiquity to the Present, eds. Volker Manuth, Rudie van Leeuwen, and A. M. Koldeweij (Turnhout, 2016), pp. 6991; Kees van der Ploeg, "Likeness and Presence in the Age before the Portrait Historié," ibidem, pp. 93-108; Intorno al ritratto. Origini, sviluppi e trasformazioni, eds. Fabrizio Crivello, and Laura Zamparo (Turin, 2019).

19 For a detailed overview, see: Tracey A. Sowerby, “'A Memorial and a Pledge of Faith': Portraiture and Early Modern Diplomatic Culture," The English Historical Review 129 (2014), 296-331.

20 Ekkehard IV, Casus Sancti Galli, chap. X, ed. Georg Heinrich Pertz, Monumenta Germaniae Historica. Scriptorum tomus 2 (Hannover, 1829), p. 123. See: Fabrizio Crivello, “' '... grecus constantinopoleos orfanos et peregrinos .... Artisti bizantini in ambito librario a nord delle Alpi nell'alto Medioevo," in L'artista a Bisanzio e nel mondo cristiano-orientale, ed. Michele Bacci (Pisa, 2007), pp. 255-68, esp. 263; Robert Bartlett, Blood Royal. Dynastic Politics in Medieval Europe (Cambridge, 2020), p. 34. 
considerations prevailed. Not infrequently, a more distinct and realistic mode of rendering was associated with royal images in funerary contexts, since these aimed to underscore - not only before human viewers but also before God the individual responsibility of the deceased, there inhumated as sinners, to make arrangements for the performance of pro anima Masses and prayers in the hope of obtaining relief from their pains in the afterlife. ${ }^{21}$ In this context, a portrait-like appearance could be attributed even to individuals whose physical features were unknown, as is evidenced by the mid-13th-century full-length statues of the margraves of Meissen in Naumburg Cathedral, who had died two hundred years earlier. 'Realism' was one of multiple representational codes instrumental in a funerary setting to emphasize the deceased's individual merits before God - and could be substituted with a more abstract code in another context. $^{22}$

For the most part, medieval royal portraits were not realistic and were not autonomous; thus it is probably misleading to speak of royal portraits at all, and it is much preferable to make use of the expression 'royal images.' This implies a notional entity that is at once larger and narrower than the one hinted at by the term 'portrait.' It includes all kinds of artistic strategies by which rulers' ambiguous physicality came to be evoked in visual form, in a multitude of media and object-types. ${ }^{23}$ In most cases, scarce efforts were made to point out individual identity, not so much because the evocation of the 'body politic' thoroughly prevailed over the material person, but because personal identity was largely understood, even outside the courtly context, in corporative, dynastic, or moral-typological terms. In most instances, it was conformity to noble and praiseworthy models that was seen - by monarchs who described themselves as new Davids, Solomons, Constantines, and later also new Charlemagnes - as indicative of one's prominent role in the world, rather than any emphasis on individual distinctiveness. ${ }^{24}$

21 Michele Bacci, Investimenti per l'aldilà. Arte e raccomandazione dell'anima nel Medioevo (Rome, 2005), pp. 155-201.

22 Peter Cornelius Claussen, "Bildnis im hohen Mittelalter," in Der Naumburger Meister. Bildhauer und Architekt im Europa der Kathedralen, eds. Guido Siebert, Hartmut Krohm, and Holger Kunde (Petersberg, 2012), pp. 227-34.

23 Dominic Olariu, La genèse de la représentation ressemblante de l'homme. Reconsidérations du portrait à partir du XIII' siècle (Bern, 2014).

24 On the different forms of medieval self-perception and their modern interpretation, see: Colin Morris, The Discovery of the Individual (New York, 1972); Aron J. Gurević, La naissance de l'individu dans l'Europe médiévale (Paris, 1997); Jean-Claude Schmitt, "La 'découverte de l'individu': une fiction historiographique?," in La fabrique, la figure et la feinte. Fictions et statut des fictions en psychologie, eds. Paul Mengal, and Françoise Parot (Paris, 1989), pp. 213-36; L'individu au Moyen Âge. Individuation et individualisation avant 
Despite the large amount of new research and the emergence of new approaches to such issues, the debate is still largely dominated by the notion of the king's two bodies as expressive of a set of mutually exclusive opposites: on the one hand, the ruler's physical, secular, individual person, which seems to be best evoked, in visual terms, by means of a realistic code and some form of physiognomic resemblance; and on the other, his or her 'body politic,' a transcendental, sacred, supra-personal double embodying the institutional authority of the state, which seems to be best evoked by the display of insignia and symbols of rulership and the adoption of an abstract, conventional, or stylized rendering of the monarch's outward appearance. Nevertheless, the interrelationship of the two dichotomic poles of Kantorowicz's metaphor is often much more blurred and inextricable than one might expect, and it is perhaps more useful to think of other, coexisting semantic nuances that take variable forms in royal images and function simultaneously as evocations of the ruler's dignity, as indicators of personal charisma, and as signifiers of juridical-political agency. ${ }^{25}$

In this respect, the basic question concerns not so much how exactly images relate to the monarch's outward appearance, but rather how, and to what extent, bodies and images alike work in re-presentational terms, as visual strategies for materializing and making present royal authority in its multiple meanings and associations, shifting from the celebration of an abstract principle not bound to any specific person to the praise of the deeds and individual qualities through which the prestige of the kingdom comes to be distinctly embodied in the incumbent ruler. ${ }^{26}$ In Byzantium, where the embodiment notion was given a specific juridical status such that the emperor's images were viewed as material and legal representatives of imperial rulership per se, attacks against statues or episodes of damnatio memoriae indicate an intention

la modernité, eds. Brigitte Miriam Bedos-Rezak, and Dominic Iogna-Prat (Paris, 2005); Brigitte Miriam Bedos-Rezak, When Ego was Imago. Signs of Identity in the Middle Ages (Leiden, 2011); Marqueurs d'identité dans la littérature médiévale. Mettre en signe l'individu et la famille (XII ${ }^{e}-X V^{e}$ siècles), eds. Catalina Girbea, Laurent Hablot, and Raluca Radulescu (Turnhout, 2014); Élisabeth Gaucher-Rémond, "De l'introspection à l'exposition de soi au Moyen Âge," Le Moyen Âge 122 (2016), 21-40.

25 On the manifestation of charisma in medieval arts and its interpretation, see: Brigitte Miriam Bedos-Rezak, and Martha D. Rust, "Faces and Surfaces of Charisma. An Introductory Essay," in Faces of Charisma: Image, Text, Object in Byzantium and the Medieval West, eds. Brigitte Bedos-Rezak, and Martha D. Rust (Leiden, 2018), pp. 1-44.

26 I use 'representation' in the antique and medieval juridical sense of 'making present,' see: Hasso Hoffmann, Repräsentation. Studien zur Wort- und Begriffsgeschichte von der Antike bis ins 19. Jahrhundert (Berlin, 1974). 
to deny the legitimacy not of the institution, but of the specific way in which it had been improperly manifested in a single individual. ${ }^{27}$ No less than the figurative objects surrogating them, rulers' bodies were regarded as visual items whose outward appearance was expected to correspond to some standardized features, the most important of which was corporeal integrity: throne usurpers need only disfigure their predecessor's face through blinding him or cutting his ears or nose, instead of killing him, since the plenitude of power was not deemed to be adequately represented (that is, made present, effective, and officially recognizable) by a mutilated body. ${ }^{28}$

In many instances, sovereigns were content with signalling their status, rather than using arts to magnify their individual qualities. Depending on the contingencies of the period in question, it could have been more politically fruitful for a ruler to either emphasize that his supremacy stemmed from his conformity to a standardized ideal of authority or, on the contrary, to emphasize his own personal charisma and authoritativeness. For an emperor like Constantius II, who did not possess his father Constantine's ability to impose his will on the many people discontented with his politics, it was probably important to publicly stress his own legitimacy: as reported in a famous passage by Ammianus Marcellinus, he appeared in public ceremonies in a posture and attire that made him look like a conventional imperial statue. ${ }^{29}$ The use of standard features also depended upon the medium and upon the functional context in which the image was displayed. Understandings of the ruler's effigy and name on coins, seals, and medals as embodiments of kingship - with the conventional or idealized rendering of the sovereign's physicality helping to evoke its institutional and transpersonal nature - were rooted in HellenisticRoman tradition and interculturally shared in the Middle Ages. The introduction of alternative designs, as in 7 th-century Merovingian Gaul, manifested the political marginalization of kings: the re-establishment of monarchic power was marked, in Carolingian times, by the reappearance of the ruler's name, and a number of special denarii celebrated Charlemagne's imperial role by displaying him in profile, in a thoroughly non-mimetic way based on Roman models. Whoever despised these signs, as Walahfrid Strabo witnessed, was

27 Eastmond, "Between Icon and Idol," pp. 79-81.

28 Patricia Skinner, Living with Disfigurement in Early Medieval Europe (University Park, 2017), esp. pp. $75^{-77}$ on the disfigurement of Byzantine emperors.

29 See esp.: Jaś Elsner, Imperial Rome and Christian Triumph. The Art of the Roman Empire AD 100-45o (Oxford, 1998), pp. 33-35. 
brought to trial and punished. ${ }^{30}$ But in many instances, until the later Middle Ages, Western European courts gave preference to even more abstract signs, such as monograms or coats of arms, which were deemed most efficacious markers of institutional legitimacy. ${ }^{31}$

In Byzantium, the image of the ruler remained standard on coins and seals, on the obverse of which was usually displayed Christ or, less frequently, the Virgin Mary, in such a way as to visually confirm that the dignity of the ruler both stemmed from and was subordinated to God. The message conveyed by this imagery was viewed, even by non-Christians, as an irremissible marker of the official documents issued by the court of Constantinople. In receptions of Byzantine ambassadors, for example, the authenticity of the official letters they brought with them could certainly be inferred from their precious appearance, but it was only through inspection of the emperor's image that it came to be verified and publicly acknowledged. This explains why the most meticulous description of a Byzantine letter has come down to us from the chronicle of an Andalusian writer, Ibn Hayyal, in his account of the 949 negotiations between Constantine VII Porphyrogennetos and the Umayyad caliph of Spain Abd al-Rahman:

This letter was written in Greek on a parchment painted in blue with golden letters. Within the roll it gave shape to there was a similarly coloured sheet filled with Greek script, that included a description and listing of the gifts sent to the Caliph. A golden seal of a weight corresponding to four mithkals was attached to the letter: on one of its sides was the image of Christ and on the other that of King Constantine with his son. The imperial letter was closed within a silver case whose golden cover included an enamelled, polychrome image of King Constantine. The case itself was housed within a cylindrical casket lined with brocade. The addressing formula of the letter read in this way: on a line, Constantine and Romanos, believers in Christ, august sovereigns, Kings of the Romans; on the other, to the holder of magnificent merits, the illustrious and noble by birth 'Abd al-Rahman, the Caliph, who rules the Arabs of al-Andalus - that Allāh may prolong the duration [of his reign]. ${ }^{32}$

30 Walahfrid Strabo, Libellus de exordiis, chap. vinI, eds. Alfred Boretius, and Victor Krause, Monumenta Germaniae Historica. Capitularia regum Francorum. 2 (Hannover, 1897), p. 483 .

31 Andreas Stieldorf, "Die Rückkehr des Königs: zur Funktion des Herrscherbildes auf Münzen," Archiv für Diplomatik 64 (2018), 27-59.

32 This passage from Ibn Hayyal's chronicle is known via the transcription made in 1628 by the Algerian historian al-Maqqarī, Nafh al-tib, book 6, chapter 5 . I have corrected the 
It is clear that, for the purposes of such official images, a formulaic evocation of the emperor's dignity and power that could be easily understood, and to some extent shared, by its Islamic recipients was much more effective than any hint at Constantine's facial features, which the Andalusian court would have ignored in any case. Nevertheless, in some specific cases it could prove useful to introduce a more individualized physiognomy. When rulers were in a position of strength and could draw political advantage from celebrating their military glory or their special merits - in particular if they managed to overcome some sort of major crisis - they did not refrain from highlighting some of their physical features in their images. They thus promoted the shaping of images in which the prestige of the royal institution was enhanced and revitalized through the staging of their personal charisma, instead of confirming their authority exclusively by visualizing their status as monarchs. For example, the display of Heraclius's exceedingly long beard on his golden coins from 629 onwards was quite recognizably at odds with earlier numismatic conventions and worked as a powerful reminder of his role as the one leader who, in return for triumph over the Persian invaders, had fulfilled the vow not to cut his facial hair. This unusual look became normative in the representations of his immediate successors, who opted for a strategy of disguise that stressed their visual conformity with the first of the Heraclids, with the aim of suggesting their complete participation in his charismatic distinctiveness and situating themselves within a lineage descending from him. ${ }^{33}$

In this way, the emperor's subjects got quickly accustomed to inferring the legal and economic validity of golden solidi from their being marked with the image of a bearded basileus, even if this contrasted with earlier visual conventions. The preference for stereotyped forms did not imply that these same

antiquated English translation by: The History of the Mohammedan Dynasties in Spain, ed. Pascual de Gayangos (London, 1840-43), 2:141-42, through comparison with the much more accurate French version by: Histoire de l'Espagne musulmane, ed. Evariste Lévi-Provençal (Paris, 1944-53), 2:152. On the episode, see: Courtney Luckhardt, “'The Messenger is the Place of a Man's Judgment': Diplomacy between Emperors and Caliphs in the Tenth Century," Medieval Worlds 8 (2018), 86-108 [DOI 10.1553/medievalworlds_ no8_2018s86, accessed 2020 July 15], here 100-01.

33 I have discussed the votive function of Heraclius's beard in: Michele Bacci, "Beards and the Construction of Facial Appearance in the Middle Ages," in The Face in Medieval Culture. East and West, ed. Oleg Voskoboynikov, (Florence: Sismel, 2022), pp. 115-31. On the Heraclids' coinage, see: Philip Grierson, Byzantine Coins (Berkeley, 1982), pp. 84-149. On the ambiguity of the ruler's image on early medieval coins from a transcultural perspective, see also: Rebecca R. Darley, "Money, Art, and Representation. The Powerful and Pragmatic Faces of Medieval Coinage," in A Cultural History of Money in the Medieval Age, ed. Rory Naismith (London, 2019), pp. 99-124. 
forms were expected to remain ever unaltered, but rather that they were constantly adapted to shifting contingencies by means of an ongoing negotiation between standard and individualized features. With the emergence of the Islamic Empire in the 7th century, caliphs first issued slightly altered imitations of Byzantine or Sasanian coins, and in a second phase, under Abd alMalik (H. 65-86/A.D. 685-705), new figural designs were explored that placed an emphasis on the stylized representation of a standing, bearded ruler, with the attributes of his role as defender of the believers and as deputy of God. Users of these coins could recognize the same mark of imperial authority that they were accustomed to, and meanwhile epigraphic elements, like the shahada or profession of faith, revealed the emperor's identity as the Prophet's successor. After the triumph over the Kharijites of Mecca (between 77/696 and 79/699), who had attempted to take leadership of the Islamic world, a purely epigraphic design came to be adopted for coins and served to underscore the Umayyad caliph's legitimate status as stemming from God. ${ }^{34}$

Undoubtedly, this new, aniconic design was a radical innovation in the numismatic imagery of Mediterranean cultures and beyond. But, as happened in other contexts as well, an evocatio per absentiam could prove even more efficacious than the sovereign's visual and physical presence: in this sense, it is worth stressing that the caliph disappeared from coins at much the same moment that his body started being concealed behind veils and curtains during public audiences as well as during the Friday prayer or khutba. ${ }^{35}$ Nevertheless, the shift to an aniconic design on coins did not mean that Muslim rulers thoroughly renounced the use of figurative objects to evoke their dignity. As recent research has stressed, two- and three-dimensional royal images were frequently displayed in the decoration of Umayyad residences. For instance, the murals at Qușayr 'Amra - probably made on the initiative of Prince al-Walid in the late 730 or or early 740 s when power was in the hands of his uncle Hisham display the prince in the glory of his longed-for throne, as a member of the ruling family (Figure. o.2), and in the act of being honoured by prominent foreign

34 The topic has been investigated intensively in recent years, see esp. the detailed overview by: Stefan Heidemann, "The Evolving Representation of the Early Islamic Empire and its Religion on Coin Imagery," in The Qur'ān in Context. Historical and Literary Investigations into the Qur'änic Milieu, eds. Angelika Neuwirth, Nicolai Sinai, and Michael Marx (Leiden, 2010), pp. 149-96.

35 Giorgio Vercellin, Tra veli e turbanti. Rituali sociali e vita privata nei mondi dell'Islam (Venice, 2000), pp. 107-10; Maaike van Berkel, "Politics of Access at the Court of the Caliph," in New Perspectives on Power and Political Representation from Ancient History to the Present Day: Repertoires of Representation, eds. Harm Kaal, and Daniëlle Slootjes (Leiden, 2019), pp. 26-36, esp. 29 and 32. 
rulers, including the Byzantine emperor, the Visigothic king, the Persian shah, and the Ethiopian negus (Figure. O.3). ${ }^{36} \mathrm{Al}$-Walid may also have been responsible, perhaps after his enthronement in 743 , for the stuccoed decoration of Khirbat al-Mafjar, near Jericho, where he was represented over the door of the audience hall (Figure. 0.4) in the typical attire of a Sasanian king, bearded and holding a sword, similar to Abd al-Malik's image on coins. ${ }^{37}$

Generic representations of figures in royal attire appear also later, though in different media and according to different schemes, in the decoration of residences, precious objects, and manuscripts associated with Islamic sovereigns. In these contexts, the royal images were not isolated but were rather part of larger programmes celebrating courtly life and pleasures, such as hunts, music and dance performances, and public audiences. ${ }^{38}$ It would be tempting, but misleading, to infer from this that the use of portrait-like effigies remained restricted to the Islamic ruler's private or domestic sphere, whereas a rigid 'aniconism' became the marker of official media, like coinage, seals, or medallions. Indeed, it is problematic to think of the decorations embellishing the sovereign's residences as private. Frequently, a whole repertory of royal and courtly figures were represented in audience halls and therefore visible to members of the court, visitors, servants, guests, and ambassadors. Nevertheless, in other cases preference was given to purely ornamental, vegetal, or geometric decor.

Recent research has shown that the semantic divide between figure and ornament, as well as between image and script, was much more fluid in Islamic thought than one might expect. ${ }^{39}$ Even within the same period and context,

36 Garth Fowden, Qușayr 'Amra. Art and the Umayyad Elite in Late Antique Syria (Berkeley, 2004); see also: Frédéric Imbert, "Le prince al-Walīd et son bain: itinéraires épigraphiques à Qușayr 'Amra," Bulletin d'études orientales 64 (2015), 321-63.

37 Robert W. Hamilton, Khirbat al Mafjar: An Arabian Mansion in the Jordan Valley (Oxford, 1959), pp. 98-103, 228-32; Donald Whitcomb, "Caliph and King: Effigies and Islamic Archaeology," in Sur les chemins d'Onagre: histoire et archéologie orientales. Hommage à Monik Kervran, eds. Claire Hardy-Guilbert, Hélène Renel, Axelle Rougeulle, and Eric Vallet (Oxford, 2018), pp. 235-45.

38 Dorothy G. Shepherd, "Banquet and Hunt in Medieval Islamic Iconography," in Gatherings in Honour of Dorothy E. Miner, eds. Ursula E. McCracken, Lilian M. C. Randall, and Richard H. Randall (Baltimore, 1974), pp. 79-92; Katharina Otto-Dorn, "Das islamische Herrscherbild im frühen Mittelalter," in Das Bildnis in der Kunst des Orients, eds. Martin Kraatz, Jürg Meyer zur Capellen, and Dietrich Seckel (Stuttgart, 199o), pp. 61-78; see also, for an overview of extant pictorial works: Richard Ettinghausen, Arab Painting (Geneva, 1962), pp. 42-50, 61-65, 92, 147-49; Maria Vittoria Fontana, La pittura islamica dalle origini alla fine del Trecento (Rome, 2002), pp. 67-72, 77-78, 84-85, 88-89, 96, 99-101, 106-07, 109-10.

39 Jamal J. Elias, Aisha' Cushion: Religious Art, Perception, and Practice in Islam (Cambridge, 2012). 
different visual codes could be exploited as alternative strategies for evoking power, depending on many factors, including local tradition, the ruler's personality, and the court's cultural, political, and religious orientation. For example, in the second half of the 12th century, one of the fiercest opposers of the Almohads - the members of a Berber puritanical movement that gradually took control over North Africa and Spain - was the king of Murcia Muhammad Ibn Mardanish (1147-1172), who seems to have deliberately promoted art forms at odds with his enemies' rejection of excessive ornament and figural motifs. If his palatine mosque within the town Alcázar stood out for its rich polychrome motifs combining vegetal scrolls and eight-pointed stars, the muqarnas of his suburban residence were embellished with scenes of courtly life (Figure. o.5) and probably also with royal images. ${ }^{40}$

In the 1140s, shortly preceding Ibn Mardanish's initiative, the Christian ruler Roger II adopted a similar programme for the muqarnas ceiling of his Cappella Palatina in Palermo. ${ }^{41}$ This makes clear that established imagery evoking institutional authority was appropriated without concern for religious distinctions. It has even been suggested that, during the short-lived Sicilian rule on Ifrīqiya (1142-1160), ${ }^{42}$ the Norman kings may have sought to disseminate the motif of the king seated cross-legged with a wine cup, which originated in Central $\mathrm{Asia}^{43}$ before being adopted by Christian rulers in

$40 \quad$ Alejandro García Avilés, "Arte y poder en Murcia en la época de Ibn Mardanish (1147-1172)," in El Mediterráneo y el arte español. Actas del XI Congreso del CEHA, eds. Joaquín Bérchez, Mercedes Gómez-Ferrer Lozano, and Amadeo Serra Desfilís (Valencia, 1998), pp. 31-37; Susana Calvo Capilla, “Et las mezquitas que habien deben seer del rey': la cristianización de Murcia tras la conquista de Alfonso X," in Alfonso Xel Sabio, ed. Isidro G. Bango Torviso (Murcia, 2009), pp. 688-94; Abigail K. Balbale, Between Kings and Caliphs: Religion and Authority in Sharq al-Andalus (1145-1244 CE), Ph.D. dissertation (Harvard University, 2012), pp. 196-97.

41 See esp.: Ernst J. Grube, and Jeremy Johns, The Painted Ceilings of the Cappella Palatina (New York, 2005). On Norman use of Islamic or Islamicized arts in combination with forms inspired by other Mediterranean traditions, see the methodological remarks by: Gerhard Wolf, "Alexandria aus Athen zurückerobern? Perspektiven einer mediterranen Kunstgeschichte mit einem Seitenblick auf das mittelalterliche Sizilien," in Lateinisch-griechisch-arabische Begegnungen, eds. Margit Mersch, and Ulrike Ritzerfeld (Berlin, 20o9), pp. 39-62.

42 This hypothesis is highly conjectural and relies exclusively on the interpretation and dating of a relief of a female musician playing flute adjacent to a seated king with a winged crown, found in the ruins of the palatial complex of Mahdiya, see: Lamia Hadda, L'architettura palaziale tra Africa del Nord e Sicilia normanna (secoli X-XII) (Naples, 2015), pp. 39-47.

43 Otto-Dorn, "Das islamische Herrscherbild," p. 64; Mirjam Gelfer-Jørgensen, Medieval Islamic Symbolism and the Paintings in the Cefalù Cathedral (Leiden, 1986), pp. 29-96; 
Armenia. ${ }^{44}$ Some decades later, Frederick II, another king of Sicily and, from 1220, Holy Roman Emperor, fostered the diffusion of public images of himself not only on his golden augustales but also in such monumental settings as the fortified access (built between 1234 and 1240) to Capua and the Neapolitan province from the bridge on the Volturno River. ${ }^{45}$ The great ruler's quest for the revitalization of visual formulas rooted in the Hellenistic and Roman past took place at much the same time that Artuqid and Seljuk rulers in Anatolia manifested an increasing interest in the display of ancient spolia and the use of idealized portraits on coins and seals. ${ }^{46}$

Traditionally, art history has described such phenomena as resurgences, revivals, and renaissances of ancient forms deemed to be aesthetically normative. Even if this holds partly true for the Middle Ages, given the authoritativeness with which the period invested past empires, ${ }^{47}$ such resurgences more importantly indicate that courts from a range of cultural and religious milieus - from Western Europe to the Eastern Mediterranean and beyond took recourse to figural objects that placed emphasis on the ruler's ambiguous physicality as a material embodiment of power and charisma. Images were just one of the manifold strategies through which kingship could be celebrated,

Tasha Vorderstrasse, “The Iconography of the Wine Drinker in 'Port St Symeon' Ware from the Crusader Era," Eastern Christian Art 2 (2005), 59-72, esp. 62-69.

44 It appears in the 1oth century sculpted decoration of Gagik Arcruni's palatine church in Att'amar: Lynn Jones, "The Church of the Holy Cross and the Iconography of Kingship," Gesta 13 (1994), 104-17, esp. 108; see also: Gohar Grigoryan, "King Gagik Arcruni's Portrait on the Church of Att'amar," in The Church of the Holy Cross of Att'amar. Politics, Art, Spirituality in the Kingdom of Vaspurakan, eds. Zaroui Pogossian, and Edda Vardanian (Leiden, 2019), pp. 416-40, esp. 431. On the politics of iconographic adaptation in Armenian representations of rulers, see: Lynn Jones, “'Abbasid Suzerainty in the Medieval Caucasus: Appropriation and Adaptation of Iconography and Ideology," Gesta 43 (2004), 143-50, and, on the Cilician context: Gohar Grigoryan, Royal Images of the Armenian Kingdom of Cilicia (1198-1375) in the Context of Mediterranean Intercultural Exchange, Ph.D. dissertation (University of Fribourg, 2017). On the cross-legged king motif in Syriac Christian contexts, see: Bas Snelders, Identity and Christian-Muslim Interaction. Medieval Art of the Syrian Orthodox from the Mosul Area (Leuven, 2010), pp. 350-54.

45 See esp.: Mirko Vagnoni, "Il significato politico delle caratteristiche iconografiche di Federico II di Svevia," Iconographica 5 (2006), 64-75.

46 Estelle J. Whelan, The Public Figure: Political Iconography in Medieval Mesopotamia (London, 2006); Suzan Yalman, “'Ala al-Din Kayqubad Illuminated: A Rum Seliuq Sultan as Cosmic Ruler," Muqarnas 29 (2012), 151-86. See also the methodologically relevant remarks by: David J. Wasserstein, "Coins as Agents of Cultural Definition in Islam," Poetics Today 14 (1993), 303-22.

47 On medieval attitudes to the past as a source of legitimacy in general, see: L'autorité $d u$ passé dans les sociétés médiévales, ed. Jean-Marie Sansterre (Brussels, 2004). 
praised, publicly exhibited, evoked, and made present in a body - whether real, ceremonially transfigured, or artfully simulated. This embodiment occurred by means of visual and ritual-performative techniques with roots in the ancient, not only Greco-Roman but also Sasanian Persian, worlds. ${ }^{48}$ Historically, it often proved politically useful to display prestigious images, evocative of antiquity, to evoke a sovereign's special status. Indeed, irrespective of their cultural or religious affiliation and even of their interest or disinterest in statues and paintings, sovereigns shared the view that their bodies were sites of supra-personal authority, which could themselves be used as efficacious visual objects.

This book presents the first outcomes of the research project "Royal Epiphanies. The King's Body as Image and Its Mise-en-scène in the Medieval Mediterranean (12th-14th Centuries)," funded by the Swiss National Research Foundation and coordinated by the present author at Fribourg University. ${ }^{49}$ Its basic aim is a comparative analysis across three Mediterranean contexts of the ways in which the sovereign's outward appearance was visually constructed, given shape, and invested with meaning. The three contexts in question are being investigated separately, though in strict synergy, by the three members of the research team: Armenian Cilicia (Gohar Grigoryan), Norman to AngevinAragonese southern Italy (Mirko Vagnoni), and the Kingdom of Aragón (Sofía Fernández Pozzo). With the aim of either verifying or deconstructing the assumption that royal images primarily served to assert leadership and authority, the first phase of the research project, the findings of which are published in the present volume, focused on the specific use medieval rulers made of figural images and the contextual roles such images were expected to play. This investigation brought to the fore the ambiguity and complexity of extant evidence: royal images appeared broadly and in a multiplicity of viewing contexts, media, and object-types; yet, equally multifarious were rulers' understandings of the aims of such images, in terms that have very little in common with modern notional divides such as secular versus religious, political versus institutional, or realistic versus typological.

A meeting held in Fribourg on the 12th and 13th of March 2019, ${ }^{50}$ was an occasion to bring together specialists from different Mediterranean countries to share in the team's systematic investigation of the functions and meanings

48 Matthew P. Canepa, The Two Eyes of the Earth. Art and Ritual of Kingship between Rome and Sasanian Iran (Berkeley, 2009).

49 See the description in the SNRF online database $P_{3}:$ http://p3.snf.ch/project-173045, accessed 2020 July 12.

50 Meanings and Functions of the Royal Portrait in the Mediterranean World (11th-15th Centuries), international workshop, Fribourg University, 12-13 March 2019. 
of royal images, including the audiences they were meant for, the specific conditions under which they were made accessible, and the viewing contexts in which they were put on display. After this initial, productive brainstorming session, the team extended the invitation to further scholars, all of whom agreed to collaborate on this collective volume. In an imaginary voyage from the Eastern to the Western Mediterranean, the essays explore the ways in which visual images were thought to evoke, act as a surrogate for, or celebrate sovereigns and sovereignty in several historical and geographic contexts: Greater Armenia and Armenian Cilicia (Rapti, Vardanyan, Grigoryan), the Byzantine Empire (Studer-Karlen), Serbia (Cvetković), the Kingdom of Hungary (Lucherini), Carolingian- to Angevin-Aragonese southern Italy (Speciale, Vagnoni, Bock), France (Leschot), Aragón (Serrano-Coll, Fernández Pozzo), León (Boto), and the wider space of cultural interactions between al-Andalus and Castile in the later Middle Ages (Ruiz Souza).

While each of these contributions stands out in terms of approach and the materials and media in question, the questions raised by the evidence are often the same. One such question concerns the relationship between royal and religious imagery, which will inescapably seem fraught if we insist on describing it as a sort of dichotomic opposition, a notion that lingers in characterizations of 'sacred kingship' as something distinct from the stricto sensu religious sphere. To the contrary, the permeability of the two dimensions is indicated, e.g. by the ways in which the ruler's image could be used to suggest his or her participation in a community of prayer and in a quest for liturgical commemoration (Rapti, Boto); the appropriation of biblical themes, such as the genealogy of Christ, for dynastic compositions in religious contexts (Vardanyan, Cvetković); the enduring tendency to bring up royal images within theological debates (Grigoryan); and the use of compositional and iconographic conventions that invested kings with a saintly look (Lucherini).

Other essays tackle the ruler's personal engagement in promoting some form of visual politics. Studer-Karlen's essay provides a wide-ranging overview of Byzantine imperial representation and its purposes, largely grounded on late antique notions of legal and political agency. If Vagnoni warns art historians against overemphasizing the propagandistic, self-promoting function of medieval royal images, other contributors observe how their dissemination was bound to the initiatives of individual monarchs, as in the Angevin context examined by Bock. Individual features could be intentionally introduced, provided that they do not distract viewers from acknowledging the monarch's institutional, transpersonal dignity. Even in France, where the court made use of a new representational code stressing to some extent individual distinctiveness, efforts were made to find an acceptable compromise between the use of 
realistic devices and the abstract evocation of sovereignty hinted at by insignia, clothing, and conventional postures (Leschot).

Despite being extremely rich in its extant evidence, the Spanish context has been largely neglected on this topic. Relying on a multiplicity of sources, Serrano-Coll examines the different functions attributed to the representations of the kings of Aragón as visual authenticators of legal agency, as ideological tools, and as objects that, to varying degrees, were instrumental in the ruler's self-presentation in courtly ceremonials. Similar uses are reflected in the Leonese documentation investigated by Boto. In the context of Aragón, Fernández Pozzo stresses the importance of clothing, posture, and the language of gestures in constructing the king's outward appearance and shows how visual conventions established in courtly ceremonials could be transmitted to imagery, and vice versa. Finally, Ruiz Souza's chapter places emphasis on the wide network of mutual interconnections that can be detected in the palatial architecture of the kingdoms of Castile and al-Andalus. He reconstructs what might be described as a shared ritual culture of kingship, in which Christian kings appropriated various strategies by which the bodies of Nasrid emirs were framed, staged, and put on display in public rituals and receptions, as evidenced, for example, in the imagery that celebrates the monarch's education and wisdom in the Hall of Justice of the Alhambra.

In short, this book provides a state of the field and an interpretive framework for the study of Mediterranean royal images as figural evocations of the ruler's presence and institutional agency. At the same time, it opens the topics that are currently the focus of the second phase of the "Royal Epiphanies" project. In this phase, the project aims to move beyond the boundaries of figural objects, which were just one among multiple media in which the ruler's body could be experienced visually. Emphasis will be placed not so much on how kings and queens were represented in painted or sculpted images but on how their outward, physical appearance was put on display, transformed, and adapted to models - whether conventional or unconventional - meant to evoke ideal notions of institutional authority, personal charisma, supernatural beauty, and moral distinction. The shift we are proposing is from images as conveyors of presence to bodies as visual indicators of kingship. This demands an attention to the different factors that contributed to the iconicity of a monarch's look (clothing, hairstyle, presence or absence of facial hair, insignia and symbols, make-up, etc.); on the specific, highly ritualized circumstances under which royal bodies were made accessible; and, finally, on the role played by spatial contexts (ornament, lighting devices, thrones, baldachins and curtains, architectural barriers, weapons, coats of arms, flowers and trees, animals, 
statues and paintings, and the physical arrangement of attendants, guards, and courtiers) in evoking the ruler's dignity and supremacy.

\section{Bibliography}

\section{Secondary Sources}

Ando, Clifford, Imperial Ideology and Provincial Loyalty in the Roman Empire (Berkeley, 2000).

Avilés, Alejandro García, "Arte y poder en Murcia en la época de Ibn Mardanish (1147-1172)," in El Mediterráneo y el arte español. Actas del XI Congreso del CEHA, eds. Joaquín Bérchez, Mercedes Gómez-Ferrer Lozano, and Amadeo Serra Desfilís (Valencia, 1998), pp. 31-37.

Bacci, Michele, Investimentiper l'aldilà. Arte e raccomandazione dell'anima nel Medioevo (Rome, 2005).

Bacci, Michele, "Beards and the Construction of Facial Appearance in the Middle Ages," in The Face in Medieval Culture. East and West, ed. Oleg Voskoboynikov, (Florence: Sismel, 2022), pp. 115-31.

Bahrani, Zainab, The Graven Image: Representation in Babylonia and Assyria (Philadelphia, 2003).

Balbale, Abigail K., Between Kings and Caliphs: Religion and Authority in Sharq alAndalus (1145-1244 CE), Ph.D. dissertation (Harvard University, 2012).

Bartlett, Robert, Blood Royal. Dynastic Politics in Medieval Europe (Cambridge, 2020).

Bauch, Kurt, Das mittelalterliche Grabbild. Figürliche Grabmäler des 11. bis 15. Jahrhunderts in Europa (Berlin, 1976).

Bedos-Rezak, Brigitte Miriam, When Ego was Imago. Signs of Identity in the Middle Ages (Leiden, 2011).

Bedos-Rezak, Brigitte Miriam, and Rust, Martha D., "Faces and Surfaces of Charisma. An Introductory Essay," in Faces of Charisma: Image, Text, Object in Byzantium and the Medieval West, eds. Brigitte Bedos-Rezak, and Martha D. Rust (Leiden, 2018), pp. 1-44.

Belting, Hans, Bild und Kult. Eine Geschichte des Bildes vor dem Zeitalter der Kunst (Munich, 1990).

Belting, Hans, Bild-Anthropologie. Entwürfe für eine Bildwissenschaft (Munich, 2001).

Bigham, Steven, Early Christian Attitudes toward Images (Rollinsford, 2004).

Bloch, Marc, Les rois thaumaturges. Étude sur le caractère surnaturel attribué à la puissance royale particulièrement en France et en Angleterre (Strasbourg, 1924).

Brubaker, Leslie, and Haldon, John F., Byzantium in the Iconoclast Era, c. 680-850 (Cambridge, 2011). 
Brubaker, Leslie, Inventing Byzantine Iconoclasm (London, 2012).

Büchsel, Martin, "Le portrait au Moyen Âge," Perspective 2 (2012), 401-o6.

Calvo Capilla, Susana, "Et las mezquitas que habien deben seer del rey': la cristianización de Murcia tras la conquista de Alfonso X," in Alfonso X el Sabio, ed. Isidro G. Bango Torviso (Murcia, 2009), pp. 688-94.

Carile, Maria Cristina, "Imperial Icons in Late Antiquity and Byzantium. The iconic image of the Emperor between Representation and Presence," Ikon 9 (2016), 75-98.

Castelnuovo, Enrico, "Il significato del ritratto pittorico nella società," in Storia d'Italia. V.2. I documenti (Turin, 1973), pp. 1031-94.

Clauss, Manfred, Kaiser und Gott. Herrscherkult im römischen Reich (Stuttgart, 1999).

Claussen, Peter Cornelius, "Bildnis im hohen Mittelalter," in Der Naumburger Meister. Bildhauer und Architekt im Europa der Kathedralen, eds. Guido Siebert, Hartmut Krohm, and Holger Kunde (Petersberg, 2012), pp. 227-34.

Claussen, Peter Cornelius, "Ritratto," in Enciclopedia dell'arte medievale 10, ed. Angela Maria Romanini (Rome, 1991-2002), pp. 33-46.

Crivello, Fabrizio, “'... grecus constantinopoleos orfanos et peregrinos .... Artisti bizantini in ambito librario a nord delle Alpi nell'alto Medioevo," in L'artista a Bisanzio e nel mondo cristiano-orientale, ed. Michele Bacci (Pisa, 2007), pp. 255-68.

Dagron, Gilbert, Empereur et prêtre. Étude sur le "césaropapisme" byzantin (Paris, 1996).

Darley, Rebecca R., "Money, Art, and Representation. The Powerful and Pragmatic Faces of Medieval Coinage," in A Cultural History of Money in the Medieval Age, ed. Rory Naismith (London, 2019), pp. 99-124.

Das Porträt vor der Erfindung des Porträts, eds. Martin Büchsel, and Peter Schmidt (Mainz, 2003).

Die Renaissance und die Entdeckung des Individuums in der Kunst, ed. Enno Rudolph (Tübingen, 1998).

Die Sakralität von Herrschaft. Herrschaftslegitimierung im Wechsel der Zeiten und Räume, ed. Franz-Reiner Erkens (Berlin, 2002).

Eastmond, Antony, "Between Icon and Idol: The Uncertainty of Imperial Images," in Icon and Word: The Power of Images in Byzantium. Studies presented to Robin Cormack, eds. Antony Eastmond, and Liz James (Aldershot, 2003), pp. 73-85.

Ekkehard IV, Casus Sancti Galli, ed. Georg Heinrich Pertz, Monumenta Germaniae Historica. Scriptorum tomus 2 (Hannover, 1829), pp. 74-147.

Elias, JamalJ., Aisha'Cushion: Religious Art, Perception, and Practice in Islam (Cambridge, 2012).

Elsner, Jaś, Imperial Rome and Christian Triumph. The Art of the Roman Empire AD 10o$45^{\circ}$ (Oxford, 1998).

Ettinghausen, Richard, Arab Painting (Geneva, 1962).

Fontana, Maria Vittoria, La pittura islamica dalle origini alla fine del Trecento (Rome, 2002). 
Fowden, Garth, Qusayr Amra. Art and the Umayyad Elite in Late Antique Syria (Berkeley, 2004).

Francis, James A., "Visual and Verbal Representation: Image, Text, Person, and Power," in A Companion to Late Antiquity, ed. Philip Rousseau (Oxford, 20o9), pp. 185-305.

Garipzanov, Ildar, The Symbolic Language of Authority in the Carolingian World (c. 751877) (Leiden, 2008).

Garrison, Eliza, Ottonian Imperial Art and Portraiture. The Artistic Patronage of Otto III and Henry II (Farnham, 2012).

Gaucher-Rémond, Élisabeth, "De l'introspection à l'exposition de soi au Moyen Âge," Le Moyen Âge 122 (2016), 21-40.

Gelfer-Jørgensen, Mirjam, Medieval Islamic Symbolism and the Paintings in the Cefalù Cathedral (Leiden, 1986).

Gell, Alfred, Art and Agency. An Anthropological Theory of Art (Oxford, 1998).

Gilbert, Maurice, La critique des dieux dans le Livre de la Sagesse (Sg 13-15) (Rome, 1984).

Grabar, André, L'iconoclasme byzantin (Paris, 1998).

Grierson, Philip, Byzantine Coins (Berkeley, 1982).

Grigoryan, Gohar, Royal Images of the Armenian Kingdom of Cilicia (1198-1375) in the Context of Mediterranean Intercultural Exchange, Ph.D. dissertation (University of Fribourg, 2017).

Grigoryan, Gohar, "King Gagik Arcruni's Portrait on the Church of Att'amar," in The Church of the Holy Cross of Att'amar. Politics, Art, Spirituality in the Kingdom of Vaspurakan, eds. Zaroui Pogossian, and Edda Vardanian (Leiden, 2019), pp. 416-40.

Grube, Ernst J., and Jeremy Johns, The Painted Ceilings of the Cappella Palatina (New York, 2005).

Gurević, Aron J., La naissance de l'individu dans l'Europe médiévale (Paris, 1997).

Hadda, Lamia, L'architettura palaziale tra Africa del Nord e Sicilia normanna (secoli XXII) (Naples, 2015).

Hamilton, Robert W., Khirbat al Mafjar: An Arabian Mansion in the Jordan Valley (Oxford, 1959).

Heidemann, Stefan, "The Evolving Representation of the Early Islamic Empire and its Religion on Coin Imagery," in The Qur'ân in Context. Historical and Literary Investigations into the Qur'ānic Milieu, eds. Angelika Neuwirth, Nicolai Sinai, and Michael Marx (Leiden, 2010), pp. 149-96.

Herring, Stephen L., Divine Substitution. Humanity as the Manifestation of Deity in the Hebrew Bible and the Ancient Near East (Göttingen, 2013).

Histoire de l'Espagne musulmane, ed. Lévi-Provençal, Evariste (Paris, 1944-53).

Hoffmann, Hasso, Repräsentation. Studien zur Wort- und Begriffsgeschichte von der Antike bis ins 19. Jahrhundert (Berlin, 1974).

Imbert, Frédéric, "Le prince al-Walīd et son bain: itinéraires épigraphiques à Quṣayr 'Amra," Bulletin d'études orientales 64 (2015), 321-63. 
Intorno al ritratto. Origini, sviluppi e trasformazioni, eds. Fabrizio Crivello, and Laura Zamparo (Turin, 2019).

Jones, Lynn, "The Church of the Holy Cross and the Iconography of Kingship," Gesta 13 (1994), 104-17.

Jones, Lynn, "Abbasid Suzerainty in the Medieval Caucasus: Appropriation and Adaptation of Iconography and Ideology," Gesta 43 (2004), 143-50.

Kahlos, Maijastina, "The Emperor's New Images - How to Honour the Emperor in the Christian Roman Empire?," in Emperors and the Divine: Rome and Its Influence, ed. Maijastina Kahlos (Helsinki, 2016), pp. 119-38.

Kantorowicz, Ernst, The King's Two Bodies. A Study in Mediaeval Political Theology (Princeton, 1947).

Körner, Hans, "Individuum und Gruppe. Fragen nach der Signifikanz von Verismus und Stilisierung im Grabbild des 13. Jahrhunderts," in Die Repräsentation der Gruppen. Texte-Bilder-Objekte, eds. Otto Gerhard Oexle, and Andrea von HülsenEsch (Göttingen, 1998), pp. 89-126.

Körntgen, Ludger, Königsherrschaft und Gottes Gnade: Zu Kontext und Funktion sakraler Vorstellungen in Historiographie und Bildzeugnissen der ottonisch-frühsalischen Zeit (Berlin, 2001).

Kosuch, Andreas, Abbild und Stellvertreter Gottes. Der König in herrschaftstheoretischen Schriften des späten Mittelalters (Cologne, 2011).

Kruse, Helmut, Studien zur offiziellen Geltung des Kaiserbildes im römischen Reiche (Paderborn, 1934).

L'autoritédu passé dansles sociétés médiévales, ed.Jean-Marie Sansterre(Brussels, 2004).

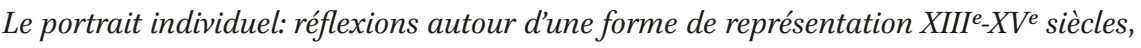
ed. Dominic Olariu (Bern, 20o9).

Le portrait: la représentation de l'individu, eds. Agostino Paravicini Bagliani, JeanMichel Spieser, and Jean Wirth (Florence, 2007).

L'individu au Moyen Âge. Individuation et individualisation avant la modernité, eds. Brigitte Miriam Bedos-Rezak, and Dominic Iogna-Prat (Paris, 2005).

Luckhardt, Courtney, “'The Messenger is the Place of a Man's Judgment': Diplomacy between Emperors and Caliphs in the Tenth Century," Medieval Worlds 8 (2018), 86108 [DOI 10.1553/medievalworlds_no8_2018s86, accessed 2020 July 15].

Marqueurs d'identité dans la littérature médiévale. Mettre en signe l'individu et la famille (XII ${ }^{e}-X V^{e}$ siècles), eds. Catalina Girbea, Laurent Hablot, and Raluca Radulescu (Turnhout, 2014).

Martindale, Andrew, Heroes, Ancestors, Relatives and the Birth of the Portrait (Maarssen, 1990).

Matthew P. Canepa, The Two Eyes of the Earth. Art and Ritual of Kingship between Rome and Sasanian Iran (Berkeley, 2009).

Morris, Colin, The Discovery of the Individual (New York, 1972). 
Niehr, Klaus, "Mimesis, Stilisierung, Fiktion in spätmittelalterlicher Porträtmalerei. Das sog. Gothaer Liebespaar," Marburger Jahrbuch für Kunstwissenschaft 25 (1998), 79-104.

Oexle, Otto Gerhard, "Memoria und Memorialbild," in Memoria. Die geschichtliche Zeugniswert des liturgischen Gedenkens im Mittelalter, eds. Karl Schmid, and Joachim Wollasch (Munich, 1984), pp. 384-440.

Olariu, Dominic, La genèse de la représentation ressemblante de l'homme. Reconsidérations du portrait à partir du XIIIe siècle (Bern, 2014).

Otto-Dorn, Katharina, "Das islamische Herrscherbild im frühen Mittelalter," in Das Bildnis in der Kunst des Orients, eds. Martin Kraatz, Jürg Meyer zur Capellen, and Dietrich Seckel (Stuttgart, 1990), pp. 61-78.

Pastoureau, Michel, "L'effervescence emblématique et les origines héraldiques du portrait au XIV ${ }^{\mathrm{e}}$ siècle," Bulletin de la Société nationale des antiquaires de France (1985), 108-15.

Pekáry, Thomas, Das römische Kaiserbildnis in Staat, Kult und Gesellschaft, dargestellt anhand der Quellen (Berlin, 1985).

Perkinson, Stephen, "Rethinking the Origins of Portraiture," Gesta 46 (2007), 135-57.

Perkinson, Stephen, The Likeness of the King: A Prehistory of Portraiture in Late Medieval France (Chicago, 2009).

Porträt, eds. Hannah Baader, Rudolf Preimesberger, and Nicola Suthor (Berlin, 1999).

Reudenbach, Bruno, "Individuum ohne Bildnis? Zum Problem künstlerischer Ausdrucksformen von Individualität im Mittelalter," in Individuum und Individualität im Mittelalter, eds. Jan A. Aerstsen, and Andreas Speyer (Berlin, 1996), pp. 807-18.

Ritratto e società. Dal Medioevo all'avanguardia, eds. Fabrizio Crivello, and Michele Tomasi (Turin, 2015).

Schmitt, Jean-Claude, "La 'découverte de l'individu': une fiction historiographique?," in La fabrique, la figure et la feinte. Fictions et statut des fictions en psychologie, eds. Paul Mengal, and Françoise Parot (Paris, 1989), pp. 213-36.

Schmitt, Jean-Claude, Le corps, le mythe, les rêves, les temps. Essais d'anthropologie médiévale (Paris, 2001).

Schramm, Percy Ernst, Die deutschen Kaiser und Könige in Bildern ihrer Zeit bis zur Mitte 12. Jahrhunderts (751-1152) (Leipzig, 1928).

Schramm, Percy Ernst, and Mütherich, Florentine, Denkmale der deutschen Könige und Kaiser. I. Ein Beitrag zur Herrschergeschichte von Karl dem Großen bis Friedrich II. (Munich, 1962).

Shepherd, Dorothy G., "Banquet and Hunt in Medieval Islamic Iconography," in Gatherings in Honour of Dorothy E. Miner, eds. Ursula E. McCracken, Lilian M. C. Randall, and Richard H. Randall (Baltimore, 1974), pp. 79-92.

Skinner, Patricia, Living with Disfigurement in Early Medieval Europe (University Park, 2017). 
Snelders, Bas, Identity and Christian-Muslim Interaction. Medieval Art of the Syrian Orthodox from the Mosul Area (Leuven, 2010).

Sowerby, Tracey A., “A Memorial and a Pledge of Faith': Portraiture and Early Modern Diplomatic Culture," The English Historical Review 129 (2014), 296-331.

Stieldorf, Andreas, "Die Rückkehr des Königs: zur Funktion des Herrscherbildes auf Münzen," Archiv für Diplomatik 64 (2018), 27-59.

al-Maqqarī, Ahmad, Nafh al-tib, transl. P. de Gayangos, The History of the Mohammedan Dynasties in Spain (London, 1840-43).

The Image of the Individual. Portraits in the Renaissance, eds. Nicholas Mann, and Luke Syson (London, 1998).

Vagnoni, Mirko, "Il significato politico delle caratteristiche iconografiche di Federico II di Svevia," Iconographica 5 (2006), 64-75.

Vagnoni, Mirko, Dei gratia rex Siciliae. Scene d'incoronazione regia nell'iconografia regia normanna (Palermo, 2017).

Vagnoni, Mirko, "Meanings and Functions of Norman Royal Portraits in the Religious and Liturgical Context: The Mosaic of the Cathedral of Monreale," Iconographica 18 (2019), 26-37.

Vagnoni, Mirko, "Royal Divine Coronation Iconography. Preliminary Considerations," Arts 8/4 (2019), 139 [https://doi.org/10.339o/arts8040139, accessed 2020 July 15].

van Berkel, Maaike, "Politics of Access at the Court of the Caliph," in New Perspectives on Power and Political Representation from Ancient History to the Present Day: Repertoires of Representation, eds. Harm Kaal, and Daniëlle Slootjes (Leiden, 2019), pp. 26-36.

van der Ploeg, Kees, "Likeness and Presence in the Age before the Portrait Historié," in Example or Alter Ego? Aspects of the Portrait Historie in Western Art from Antiquity to the Present, eds. Volker Manuth, Rudie van Leeuwen, and A. M. Koldeweij (Turnhout, 2016), pp. 93-108.

Veelenturf, Kees, "In the Guise of a Christian: The Early Medieval Preliminary Stage of the Portrait Historié," in Example or Alter Ego? Aspects of the Portrait Historié in Western Art from Antiquity to the Present, eds. Volker Manuth, Rudie van Leeuwen, and A. M. Koldeweij (Turnhout, 2016), pp. 69-91.

Vercellin, Giorgio, Tra veli e turbanti. Rituali sociali e vita privata nei mondi dell'Islam (Venice, 2000).

Vorderstrasse, Tasha, “The Iconography of the Wine Drinker in 'Port St Symeon' Ware from the Crusader Era," Eastern Christian Art 2 (2005), pp. 59-72.

Walahfrid Strabo, Libellus de exordiis, eds. Alfred Boretius, and Victor Krause, Monumenta Germaniae Historica. Capitularia regum Francorum. 2 (Hannover, 1897), pp 473-516.

Warmind, Morten Lund, "The Cult of the Roman Emperor before and after Christianity," in The Problem of Ritual, ed. Tore Ahlbäck (Abo, 1993), pp. 211-20. 
Wasserstein, David J., "Coins as Agents of Cultural Definition in Islam," Poetics Today 14 (1993), 303-22.

Weinfurter, Stefan, "Idee und Funktion des 'Sakralkönigtums' bei den ottonischen und salischen Herrschern (10. und 11. Jahrhundert)," in Legitimation und Funktion des Herrschers. Vom ägyptischen Pharao zum neuzeitlichen Diktator, eds. Rolf Gundlach, and Hermann Weber (Stuttgart, 1992), pp. 99-127.

Whelan, Estelle J., The Public Figure: Political Iconography in Medieval Mesopotamia (London, 2006).

Whitcomb, Donald, "Caliph and King: Effigies and Islamic Archaeology," in Sur les chemins d'Onagre: histoire et archéologie orientales. Hommage à Monik Kervran, eds. Claire Hardy-Guilbert, Hélène Renel, Axelle Rougeulle, and Eric Vallet (Oxford, 2018), pp. 235-45.

Wolf, Gerhard, Schleier und Spiegel. Traditionen des Christusbildes und die Bildkonzepte der Renaissance (Munich, 2002).

Wolf, Gerhard, "Alexandria aus Athen zurückerobern? Perspektiven einer mediterranen Kunstgeschichte mit einem Seitenblick auf das mittelalterliche Sizilien," in Lateinisch-griechisch-arabische Begegnungen, eds. Margit Mersch, and Ulrike Ritzerfeld (Berlin, 2009), pp. 39-62.

Wright, Georgia Sommers, "The Reinvention of the Portrait Likeness in the Fourteenth Century," Gesta 39 (2000), 117-34.

Yalman, Suzan, "Ala al-Din Kayqubad Illuminated: A Rum Seliuq Sultan as Cosmic Ruler," Muqarnas 29 (2012), 151-86. 


\section{Illustrations}

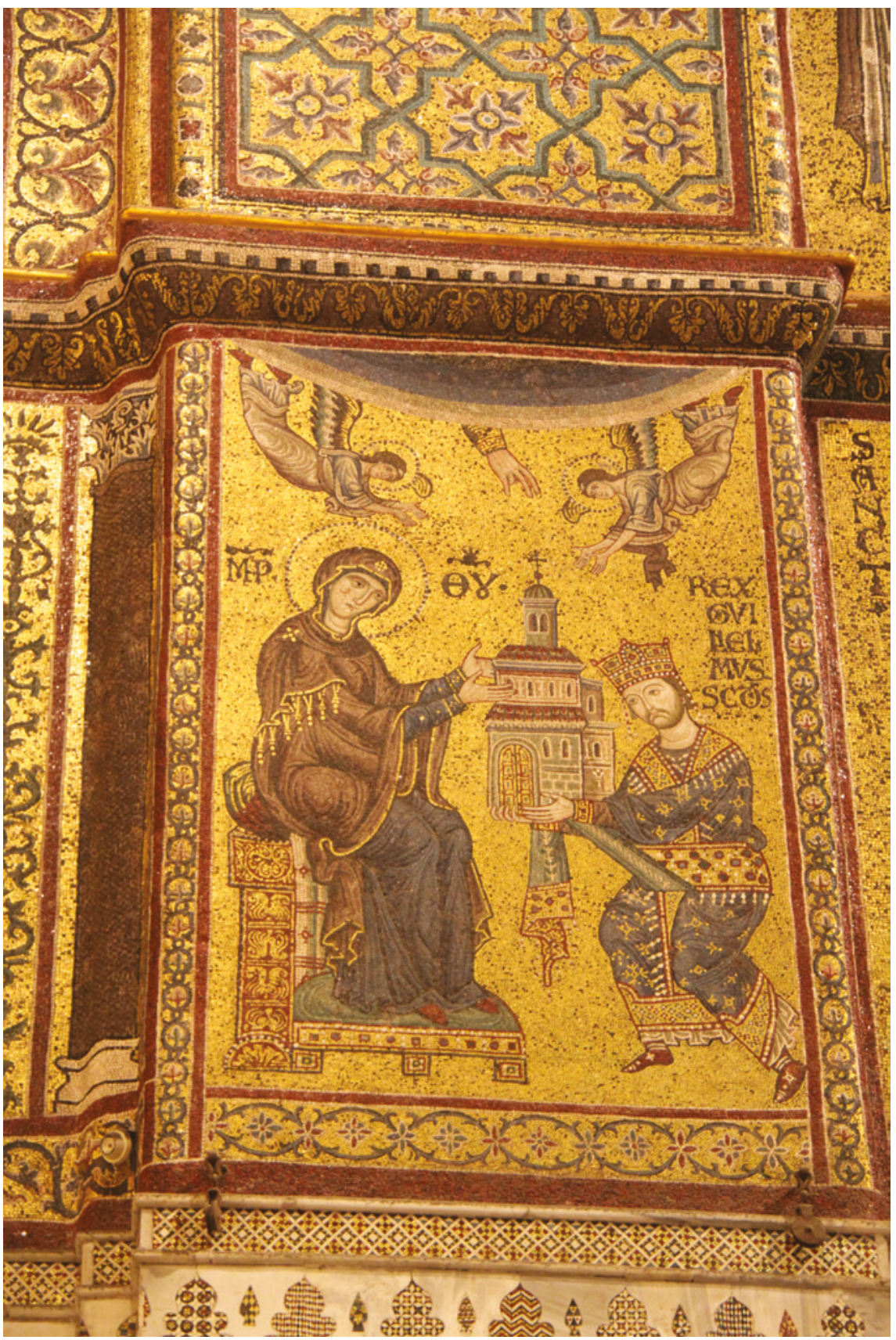

FIG URE 0.1 The Norman King of Sicily William II offers the church to the Virgin, mosaic, 11771183. Monreale Cathedral PHOTO: MICHELE BACCI 


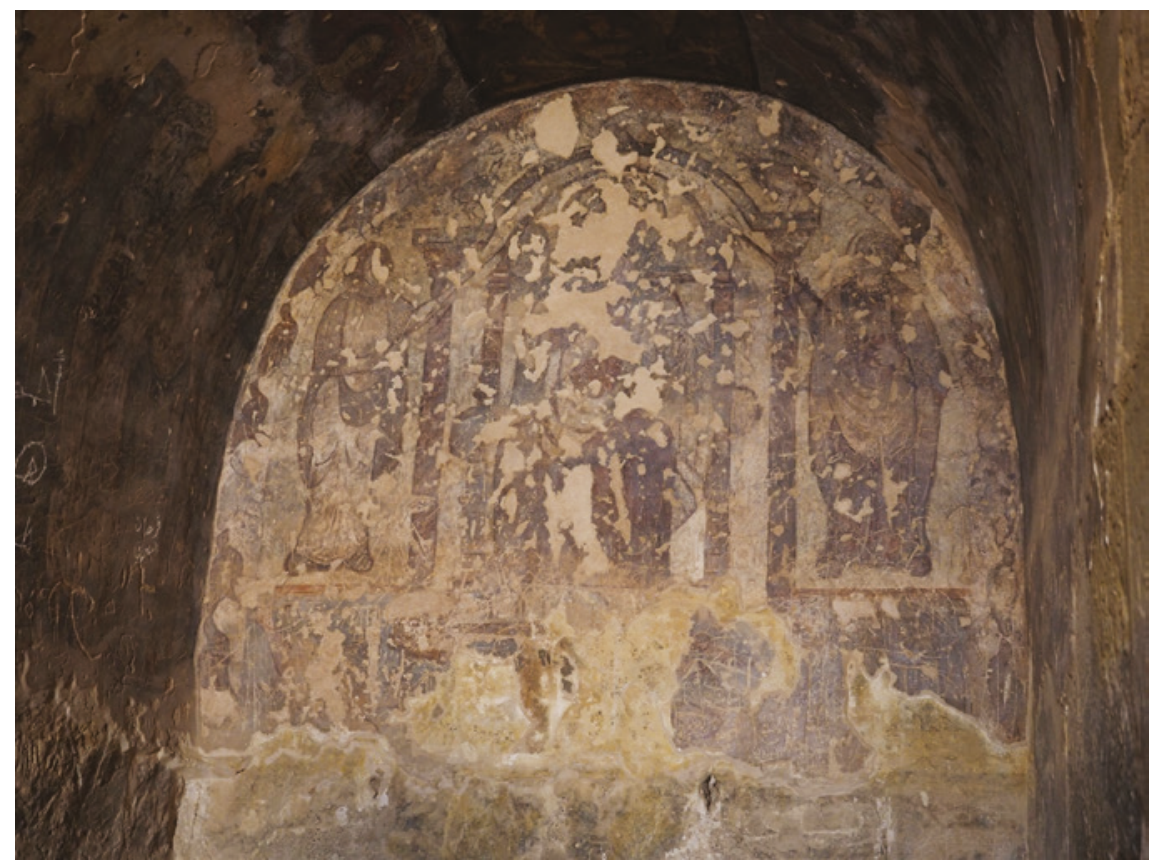

FIGURE 0.2 The Caliph enthroned, wall painting, ca. 740. Qușayr 'Amra, 'Umayyad residence PHOTO: MIRKO VAGNONI 


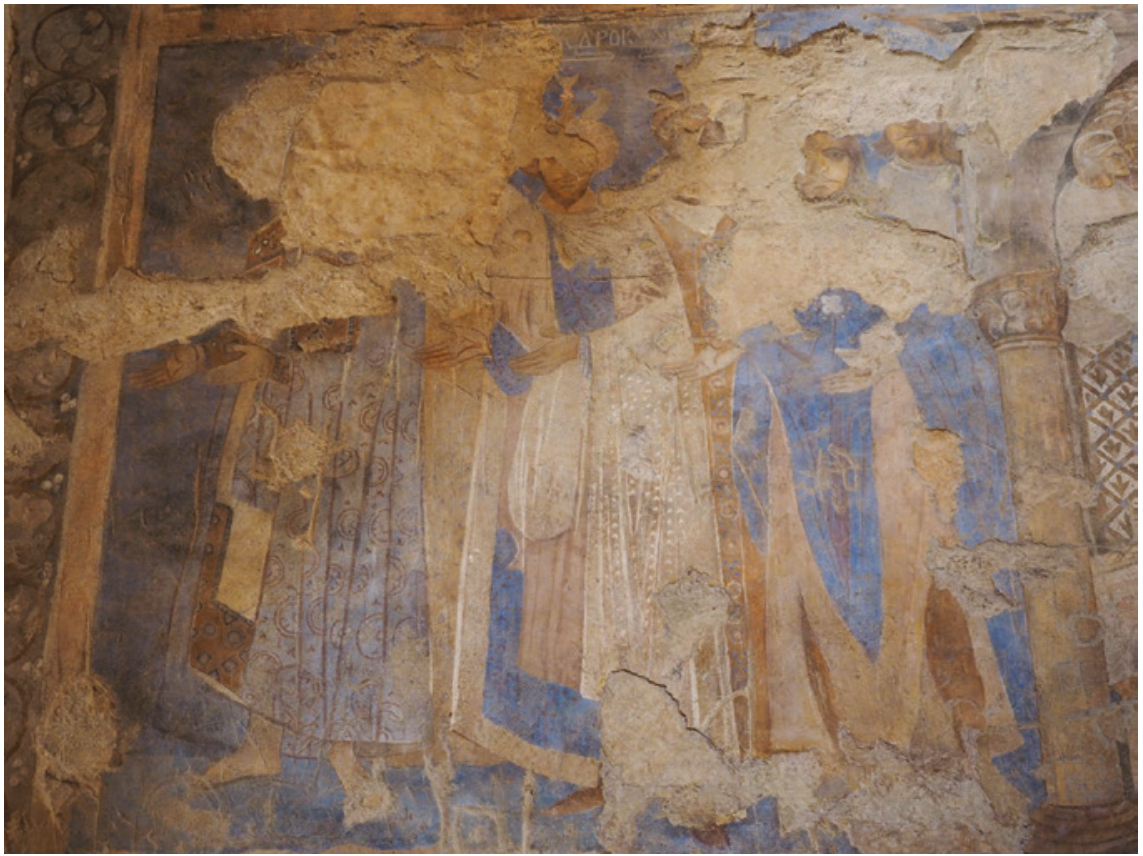

FIGURE 0.3 The six world rulers, wall painting, ca. 740. Qușayr 'Amra, 'Umayyad residence PHOTO: MIRKO VAGNONI 


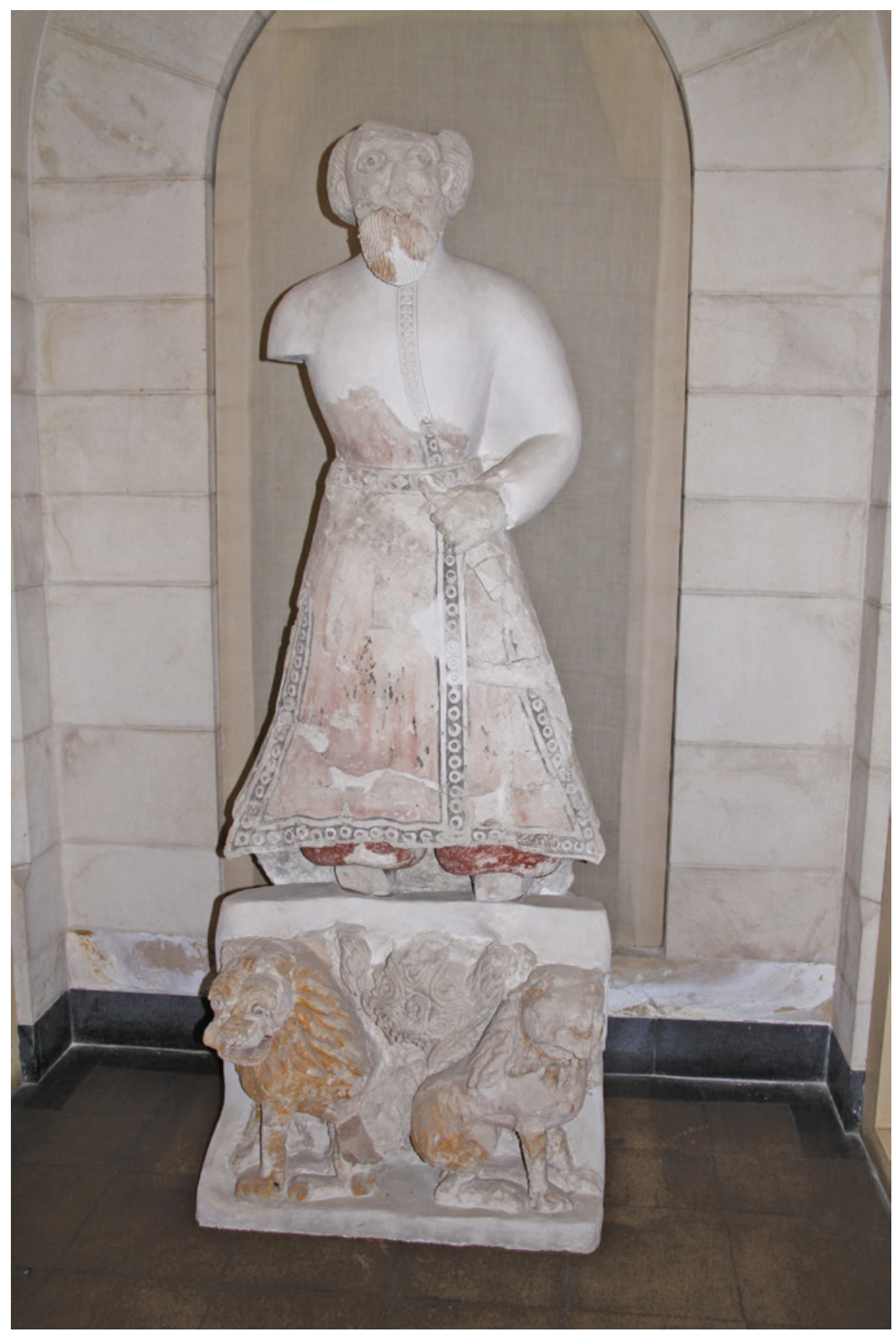

FIGURE 0.4 Standing caliph, stucco relief, 1st half of the 8th century, from Khirbat al-Mafjar. Jerusalem, Rockefeller Museum

PHOTO: MICHELE BACCI 


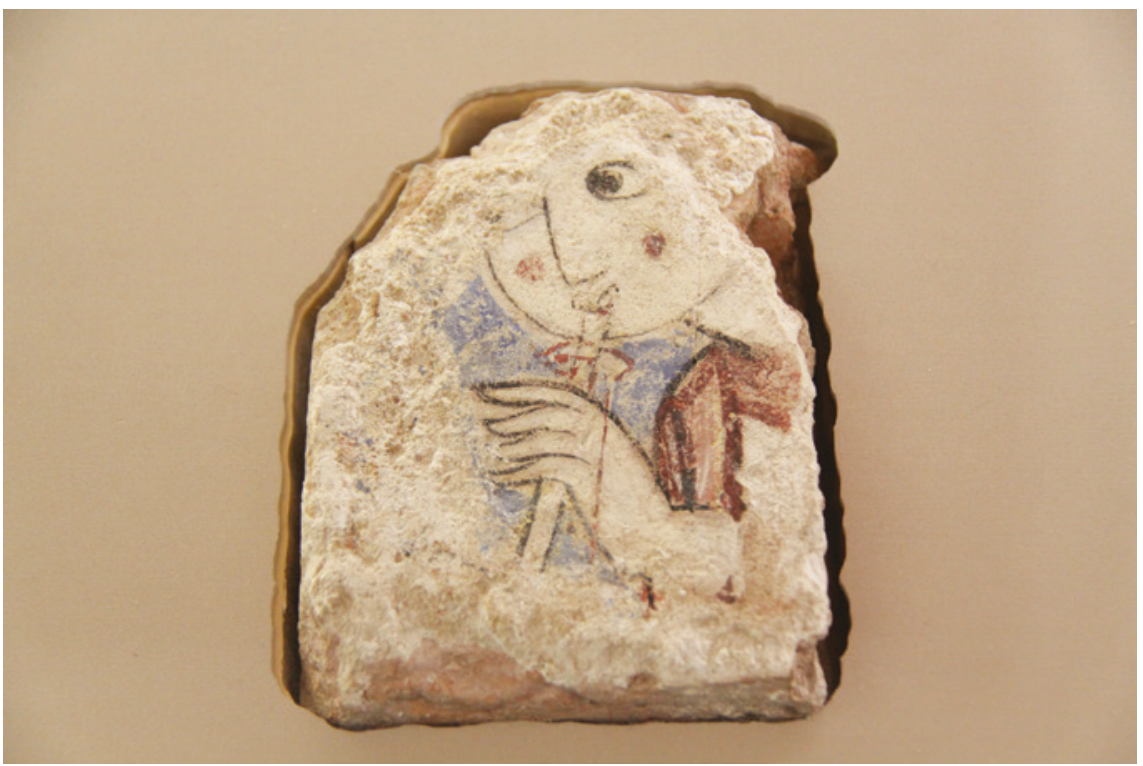

FIGURE 0.5 Musician playing a flute, fragment from a wall painting with courtly scenes, 11471172. Murcia, Museo de Santa Clara

PHOTO: MICHELE BACCI 